\title{
Typhoid Fever Profiles at Cut Meutia Hospital, North Aceh, Indonesia, in 2016-2017
}

Division of Pediatric, Faculty of Medicine, Universitas Malikussaleh, Aceh, Indonesia

\begin{abstract}
Purpose - This study aimed to describe the typhoid fever profiles based on the examination of IgM anti Salmonella in Cut Meutia Hospital, North Aceh, Indonesia, in 2016-2017.

Design/Methodology/Approach - IgM anti-Salmonella is a serological test which more quickly and accurately diagnoses typhoid fever. This is a cross-sectional study that used secondary data from medical records of a pediatric unit of patients diagnosed with typhoid fever from September 2016 to September 2017. This research identified 469 children based on age, sex, length of stay (LOS), and IgM anti-Salmonella test by univariate analysis.

Findings - The results showed that 56 children (12\%) aged 1-5 years old, 164 children (34.9\%) aged 6-11 years old, and 246 children $(53.1 \%)>12$ years old, and among them, $46.8 \%$ were male. There were $53.7 \%$ who had $+\geq 6$ of IgM anti-Salmonella test and $46.3 \%$ had +4 to +5 . We found that LOS less than 7 days was $81.4 \%$ and LOS more than 7 days was $18.6 \%$. Typhoid fever profiles in Cut Meutia Hospital were common in children aged $>12$ years old, females, had $+\geq 6$ of IgM anti-Salmonella test, and LOS less than 7 days.

Research Limitations/Implications - Typhoid fever is an acute systemic infection caused by Salmonella enteric, a serotype typhi. Typhoid fever commonly attacks children and the symptoms experienced were lighter than adults.

Practical Implications - LOS in children with typhoid fever in this research concluded that there were more children with LOS $<7$ days compared with those with a duration of $\geq 7$ days, that is 382 children $(81.4 \%)$ and 87 children (18.6\%), respectively.

Originality value - From this research, it is concluded that there were 217 children $(46.3 \%)$ diagnosed with typhoid fever with IgM anti-Salmonella test ranging from +4 up to +5 and 252 children (53.7\%) with IgM anti-Salmonella test $\geq 6$.
\end{abstract}

Keywords Typhoid fever, IgM anti-Salmonella, profiles, children

All papers within this proceedings volume have been peer reviewed by the scientific committee of the Malikussaleh International Conference on Multidisciplinary Studies (MICoMS 2017).

\section{Introduction}

Typhoid fever is transmitted through foods and drinks that are already contaminated by Salmonella typhi (S. typhi) which affect the reticuloendothelial system, intestinal lymph nodes, and gallbladder (Karande and Zaki, 2011). Typhoid fever tends to happen in children

(C) Mauliza and Julia Fitriany. Published in the Emerald Reach Proceedings Series. Published by Emerald Publishing Limited. This article is published under the Creative Commons Attribution (CC BY 4.0) licence. Anyone may reproduce, distribute, translate and create derivative works of this article (for both commercial and non-commercial purposes), subject to full attribution to the original publication and authors. The full terms of this licence may be seen at http://creativecommons.org/ licences/by/4.0/legalcode

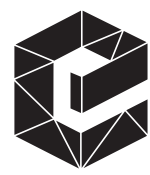

Emerald Reach Proceedings Series Vol. 1 Emerald Publishing Limited 2516-2853 DOI 10.1108/978-1-78756-793-1-00031 
Proceedings of MICoMS 2017

\section{6}

and the symptoms will be usually milder compared with adults (Inawati, 2013). The disease is common quite among children; the cause of the disease may be probably because of sanitation and immunity system that is not completely developed in children (Putu, 2013).

The incidence of typhoid fever around the world is quite large. World Health Organization (WHO) predicts that there are about 16 up to 33 millions cases of typhoid fever worldwide with 600 thousands of death each year (Masriadi and Susniati, 2013). The incidence of typhoid fever in the South East Asia is still high enough. The average morbidity rate of typhoid fever in five countries of Asia (India, China, Indonesia, Pakistan, and Vietnam) is about 180 up to 494 cases in 100,000 population for 5-15 years old children and about 149 up to 573 cases in 100,000 population for 2-4 years old children (Hedimo, 2013).

The incidence of typhoid fever in Indonesia is estimated to be about 800 cases in 100,000 population each year, with the mortality rate of $2 \%$ (Widoyono, 2011). The cases spread prevalent in all provinces of Indonesia with the incidence of 358 cases in 100,000 population in the rural area and 760 cases in 100,000 population in the urban area or about 1.5 millions cases each year. The incidence among the range of age 5-15 years old reported to be 180.3 cases in 100,000 population (Sidabutar and Satari, 2010).

The result of Riset Kesehatan Dasar (Riskesdas) in 2007 found that the prevalence of typhoid in Indonesia is $1.6 \%$, and among all the provinces, Nanggroe Aceh Darussalam (NAD) had the highest prevalence with $2.96 \%$. After further research, it was found that most of the cases occurred in North Aceh district. According to the data from Cut Meutia Hospital, North Aceh, Indonesia in 2013, there were 233 cases of typhoid fever (Dinkes, 2013).

\section{Research methods}

This is a cross-sectional study that used secondary data from medical records of a pediatric unit of patients diagnosed typhoid fever from September 2016 to September 2017 in Cut Meutia Hospital, North Aceh, Indonesia. The population of this research were all children who suffered from typhoid fever and were treated in Cut Meutia Hospital and their ages were 1-18 years, unmarried, had $+\geq 4$ of IgM anti-Salmonella test. We excluded children who diagnosed typhoid fever with Widal test result, and they went home with no permission from the doctor (went home with own request) with uncompleted data. This research used total sampling technique.

\section{Results and discussion}

The data were obtained from the medical records of the pediatric unit of Cut Meutia Hospital, North Aceh, Indonesia, from the period September 2016 up to September 2017 on 469 patients who become the sample of this research according to the inclusion and exclusion criteria. The children with typhoid fever were diagnosed using IgM antiSalmonella test and 252 children $(53.7 \%$ ) had $\geq+6$ of IgM anti-Salmonella test compared with 217 children $(46.3 \%)$ who had +4 to +5 . The result can be seen in Figure 1 .

The age of children with typhoid fever was mostly in the range of 12-18 years old as much as 249 children (53.1\%) and the lowest in the range of $0-5$ years old with 56 children $(12 \%)$, meanwhile there were 164 children $(34.9 \%)$ in the range of age $6-11$ years old. The result can be seen in Figure 2.

According to the sex, from 469 children with typhoid fever there were more female patients compared with the male with 241 children $(51.4 \%)$ and 228 children $(46.8 \%)$, respectively. The result can be seen in Figure 3.

According to the duration of treatment, there were more children with a duration of treatment $<7$ days compared with those with a duration of $\geq 7$ days that is 382 children $(81.4 \%)$ and 87 children $(18.6 \%)$, respectively. The result can be seen in Figure 4. 


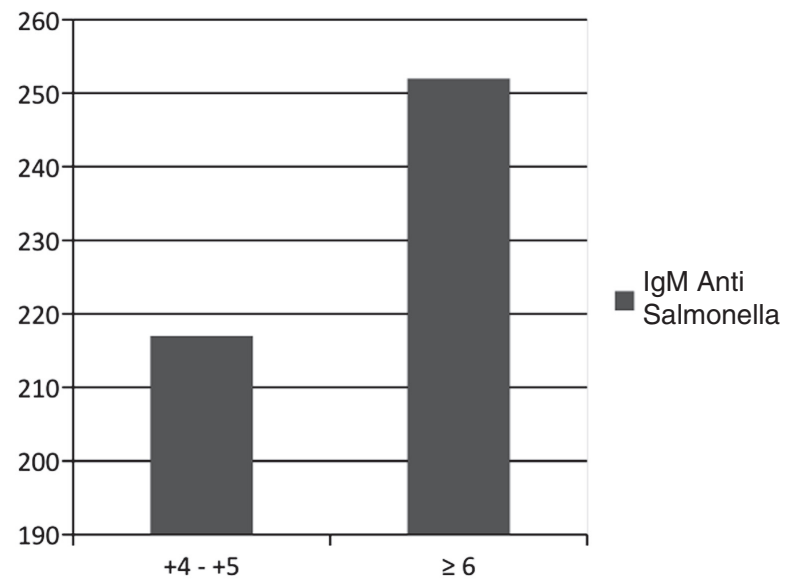

Typhoid Fever

Profiles at Cut

Meutia

Hospital

397

Figure 1.

The Comparison of IgM anti-Salmonella

Test of the Children

with Typhoid Fever

in Cut Meutia

Hospital

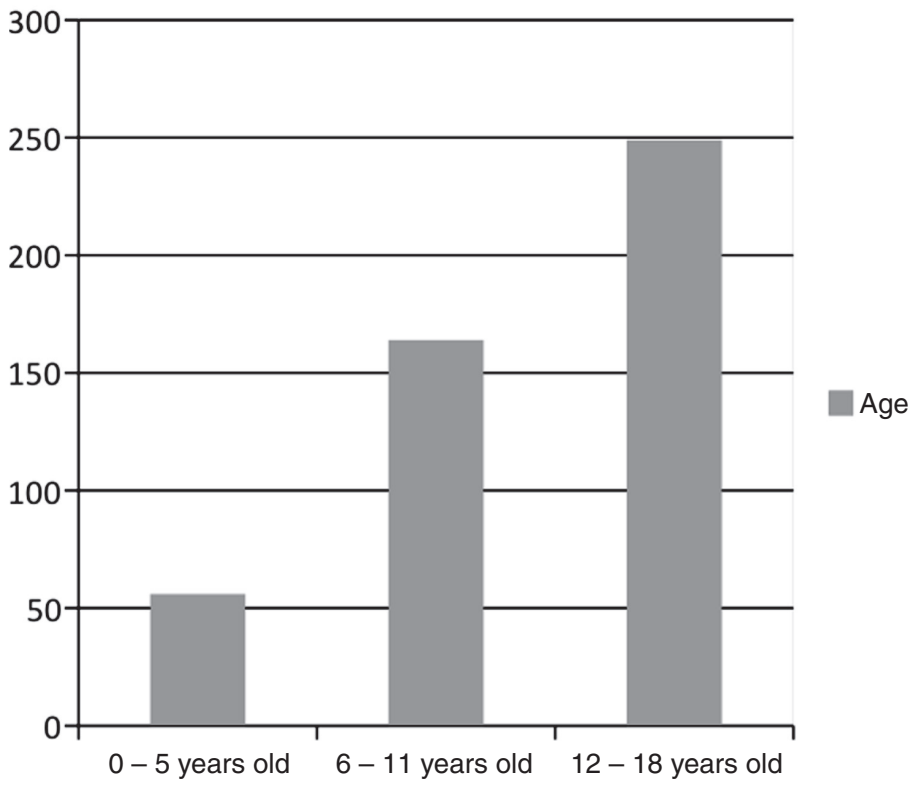

Figure 2.

The Comparison of Age of the Children with Typhoid Fever in Cut Meutia Hospital

The infection of Salmonella is the cause of gastroenteritis disorder and bacteremia in the world. The consumption of food and drink that are already contaminated with those bacteria is the high-risk factor to get infected from Salmonella. S. typhi and Salmonella paratyphi are the cause of morbidity and mortality in the developing countries (Christenson, 2013). This research used secondary data obtained from medical records of pediatric unit of Cut Meutia Hospital, North Aceh, by took the data 1 year before this research started from the September 2016 up to September 2017.

From this research, the results show that there were 217 children $(46.3 \%)$ diagnosed typhoid fever with IgM anti-Salmonella test range from +4 up to +5 and 252 children 
Proceedings of MICoMS 2017

\section{8}

\section{Figure 3.}

The Comparison of Sex of the Children with Typhoid Fever in Cut Meutia Hospital

\section{Figure 4.}

The Comparison Length of Stay in the Children with Typhoid Fever in Cut Meutia Hospital
(53.7\%) with IgM anti-Salmonella test $\geq 6$. Within the range of score +4 up to +5 , the youngest age of the children that got infected found at the age of 6 -month old and the oldest at 17 years old with the IgM anti-Salmonella test of both are +4 . With the score of $\geq 6$, the youngest found at the age of 3-month old with the IgM anti-Salmonella test +8 and the oldest at 17 years old with the IgM anti-Salmonella test was +10 . This IgM anti-Salmonella test is only able to detect IgM without IgG. The antibody response of $S$. typhi that can be detected by the IgM anti-Salmonella test is the IgM that appear in the acute infection, so that the positive result will be achieved if the blood sample from the patients consists of S. typhi IgM. (Laboratorium Nikki Medika, 2008).

The age of children with typhoid fever in this research is from the highest to the lowest were in the range of $12-18$ years old with 249 children (53.1\%), in the range of 6 - 11 years old with 164 children $(34.9 \%$ ) and the lowest from in the range of $0-5$ years old with 56 children $(12 \%)$. The research that was conducted in Kibera from 2007 to 2009 by the Kenya Medical Research Institute-Centers for Disease Control and Prevention Collaboration (KEMRI-CDC), found that the most common range of age was $10-17$ years old $(12.7 \%)$ got
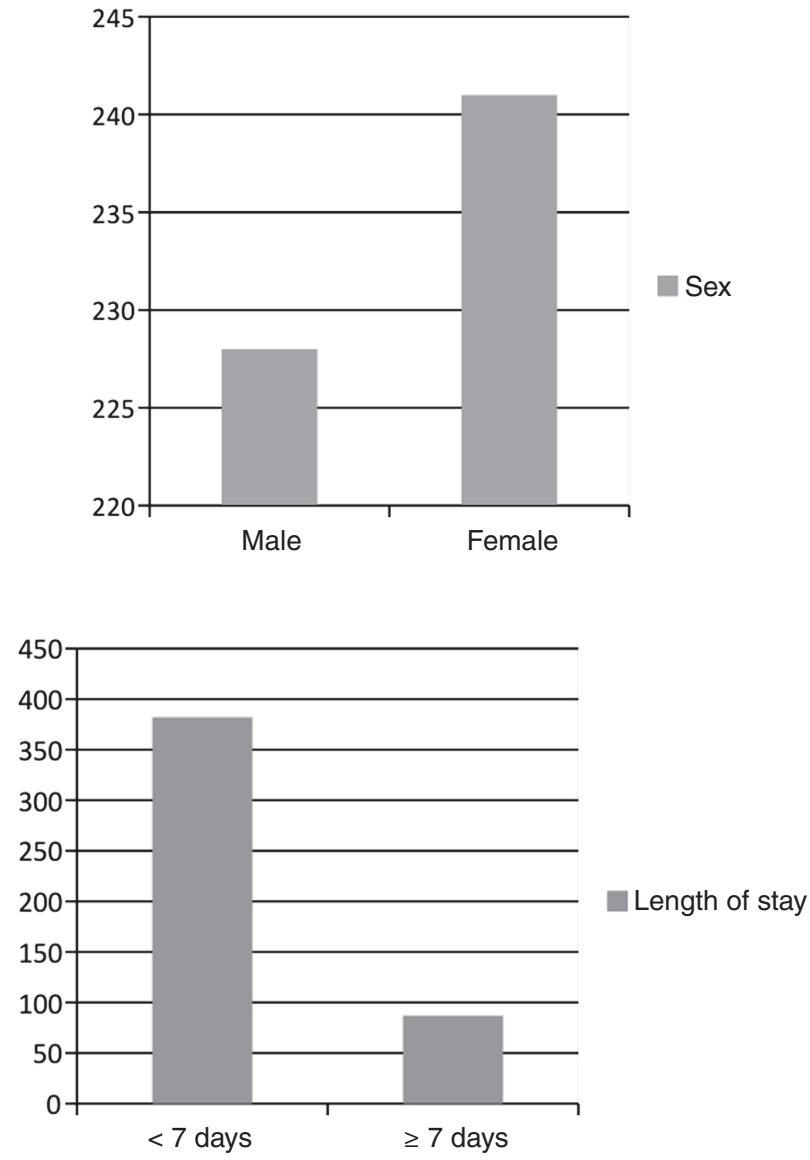
infected by the S. typh $i$ from the blood culture then followed by the range of 5-9 years old $(10.6 \%)$ (Breiman et al., 2012). The research with case-control design was conducted by the Foodborne Diseases Active Surveillance Network (FoodNet) for 24 months from 2002 to 2004 in 8 cities of the USA (Connecticut, Minnesota, Oregon, California, Colorado, Georgia, New York, and Tennessee), and it found that about 442 children $<1$ years old suffered from salmonellosis that caused by the exposure to several risk factors such as travelling outside the city, the foods and drinks that were contaminated by the reptile, contamination of children who suffered of diarrhea in the daycare, the children that were put in the shopping cart that contaminated with meat and poultry, consume of half-boiled egg, and others (Jones et al., 2006) Other research that was conducted in Tanzania in 2008-2009, in the range of age 2 months old up to 14 years old, found that $9 \%$ of the children got infected by $S$. typhi that from the blood culture (Mtove et al., 2010) There is a literature stating that the prevalence of typhoid fever about $91 \%$ occurred in the range of 3-19 years old, the incidence increase after 5 years old (Pudjiadi et al., 2009) This finding is suitable with the data from this research.

In this research, the female children tend to suffer from typhoid fever compared with the male children with 241 children $(51.4 \%)$ and 228 children $(46.8 \%)$, respectively. This research is suitable with other research that were conducted in three provinces of Indonesia (South Sulawesi, Jayapura, and East Kalimantan) in 2010-2011, and it was that the female children tend to suffer from typhoid fever compared with the male children with $52.8 \%$ and $47.2 \%$, respectively (Alba et al., 2016). Other research conducted by Kasturba Medical College Hospital, Attavar, in 1999-2001, also found that the female tend to suffer from typhoid fever compared with the male with $52.3 \%$ and $47.7 \%$, respectively (Chowta et al., 2005). Length of stay (LOS) in the children with typhoid fever in this research achieved that there were more children with LOS $<7$ days compared with those with a duration of $\geq 7$ days that is 382 children $(81.4 \%)$ and 87 children (18.6\%), respectively. This research is not in accordance with the research that were conducted to the children with typhoid fever in Royal Alexandra Hospital in 1981-1995 and Westmade Hospital in 1990-1995, where it was found that the average amount of treatment duration was 10 days with the range up to 19 days (Michael et al., 1997). The cross-sectional research that was conducted at the Department of Pediatric at Fatmawati Hospital, Jakarta in January 2001-December 2002 found that the duration of treatment of the children with typhoid fever that given the therapy of chloramphenicol and ceftriaxone was 6.5 days and 4.4 days, respectively (Musnelina et al., 2004). The research conducted by Sidabutar and Satari (2010) at the Department of Pediatric at Cipto Mangunkusumo Hospital, Jakarta, in 2010 found that the children with typhoid fever that given the therapy of ceftriaxone had shorter duration of treatment compared with them that given chloramphenicol (Sidabutar and Satari, 2010).

\section{Conclusion}

The data from medical records of a pediatric unit of Cut Meutia Hospital, North Aceh, Indonesia, from the period September 2016 up to September 2017 were obtained for 469 patients who become the sample of this research according to the inclusion and exclusion criteria. The children with typhoid fever were diagnosed using IgM anti-Salmonella test and 252 children $(53.7 \%)$ had $\geq+6$ of IgM anti-Salmonella test compared with 217 children $(46.3 \%)$ who had +4 to +5 . There were more female patients compared with the male with 241 children $(51.4 \%)$ and 228 children $(46.8 \%)$. More children with the duration of treatment $<7$ days compared with those with the duration of $\geq 7$ days that is 382 children $(81.4 \%)$ and 87 children $(18.6 \%)$. 


\section{Proceedings of References}

MICoMS 2017 Alba, S., Bakker, M.I, Hatta, M., Scheelbeek, P.F., Dwiyanti, R., Usman, R., Sultan, A.R., et al. (2016). "Risk Factor of Typhoid Infection in the Indonesian Archipelago". PLoS One, Vol. 11, No. 6, pp. 1-14.

Breiman, R.F., Cosmas, L., Njuguna, H., Audi, A., Olack, B., Ochieng, J.B., Wamola, N., et al. (2012). "Population-Based Incidence of Typoid Fever in an Urban Informal Settlement and a Rural Area in Kenya: Implications for Typhoid Vaccine Use in Africa". PLoS One, Vol. 7, No. 1, pp. 1-10.

Chowta, M.N. and Chowta, N.K. (2205). "Study of Clinical Profile and Antibiotic Response in Typoid Fever". "Indian J Med Microbiol". Vol. 23, No. 2, pp. 125-127.

Christenson, J.C. (2013). "Salmonella Infection”. Pediatric in Review, Vol. 34, No. 9, pp. 375-383.

Dinas Kesehatan Aceh Utara. (2013). "Prevalensi Penyakit Demam Tifoid 2013 di Aceh Utara”. Dinas Kesehatan Aceh Utara.

Hedimo, M. (2013). "Hubungan perilaku keluarga dengan kejadian demam tifoid pada anak di wilayah kerja puskesmas Mongolato", Jurnal S1 Keperawatan, Universitas Negeri Gorontalo.

Inawati. (2013). "Demam tifoid", Karya Tulis Ilmiah, Departemen PA, Dosen Fakultas Kedokteran Universitas Wijaya Kusuma. Surabaya.

Jones, T.F., Ingram, A., Fullerton, K.E., Marcus, R., Anderson, B.J., McCarthy, P.V., Vugia, D., Shiferaw, B., Haubert, N., Wedel, S., Angulo, FJ. (2006). "A Case-Control Study of the Epidemiology of Sporadic Salmonella Infection in Infants”. Pediatric, Vol. 118, No. 6, pp. 2380-2387.

Karande, S. and Zaki, S.A. (2011). "Multidrug-resistant Typhoid Fever". The Journal of Infection in Developing Countries, Vol. 5, No. 5, pp. 324-337.

Laboratorium Nikki Medika. (2008). "Diagnosa Tifoid Definitif, Semi Kuantitatif Dengan Metode IMBI", Brosur Denpasar. Available: http://www.ndc.co.id, [accessed October 2017].

Masriadi and Susniati. (2013), "Factors related to thypoid fever incident in Salewangan General Hospital”. Karya Tulis Ilmiah, Bagian Epidemiologi Sekolah Tinggi Ilmu Kesehatan Tamalatea. Makassar.

Michael, S., Peter, M., Joanne, M. and Bruce, F. (1997). "Typhoid Fever in Children: Diagnostic and Therapeutic difficulties". The Pediatric Infectious Disease Journal, Vol. 6. No. 7, p. 713-714.

Mtove, G., Amos, B., Seidlein, L.V., Hendriksen, I., Mwambuli, A., Kimera, J., Mallahiyo, R., et al. (2010). "Invasive Salmonellosis among Children Admitted to a Rural Tanzanian Hospital and a Comparison with Previous Studies”. PLoS One, Vol. 5, No. 2, pp. 1-8.

Musnelina, L., Afdhal, A.F., Gani, A. and Andayani, P. (2004). “Analisis Efektivitas Biaya Pengobatan Demam Tifoid Anak menggunakan Kloramfenikol dan Seftriakson di Rumah Sakit Fatmawati Jakarta Tahun 2001-2002”. Makara Kesehatan, Vol. 8, No. 2, pp. 59-64.

Pudjiadi, A.H., Hegar, B., Handryastuti, S., Idris, N.S., Gandapura, E.P. and Harmoniati, E.D. (2009). "Pedoman Pelayanan Medis Ikatan Dokter Anak Indonesia". pp. 47-50.

Putu, S. (2013). "Demam tifoid pada anak", Makalah Tifoid, Fakultas Kedokteran Universitas Wijaya Kusuma. Surabaya.

Sidabutar, S. and Satari, H.I. (2010). "Pilihan terapi empiris demam tifoid pada anak: kloramfenikol atau seftriakson". Journal Sari Pediatri, Vol. 11, No. 6, pp. 434-435.

Widoyono. (2011). "Penyakit tropis", Erlangga, Jakarta.

\section{Corresponding author}

Mauliza can be contacted at mauliza@unimal.ac.id 